\title{
In search for effective methods of routine formation
}

Marcin Kandora, Ph.D. Integration Manager, Imperial Brands PLC

\section{Introduction}

Organizational routines are ubiquitous in organizations (Becker, 2008), providing direction and influence on the way organizational members act. Some of them emerge spontaneously, others are consciously planned, designed and implemented. They can be seen as "(..) repetitive, recognizable patterns of interdependent actions, carried out by multiple actors." (Feldman, Pentland 2003, p. 95). Organizational routines are: of processual nature, path and context dependent, being triggered by actor-related and external cues, stored in procedural memory, difficult to replicate and transfer, and objects with blurred boundaries (extensively on routine characteristics in: Becker 2004, pp. 644-654).

Routinization helpstoreduce therandomness of activities, decreases the number of trial and error actions and allows to limit searching for solutions to known issues. It permits to better focus on strategic themes and habitually execute necessary operational processes. As such, it facilitates coordination and control (Nelson, Winter 1982) (March, Olsen 1989) and reduces uncertainty (Becker 2004). Routines mitigate conflicts by fostering truce (Nelson, Winter 1982, pp. 107-112). They constitute a significant part of the organizational memory 
(Nelson, Winter 1982, pp. 99-107) by storing tacit knowledge of collective nature (Becker 2004, pp. 660-661), especially the knowledge related to the processes of transforming inputs into outputs (Walsh, Ungson 1991, p. 65). Routines ensure continuity and stability (March, Simon 1958) (Cyert, March 1963), as well as „(...) efficiency, legitimacy, accountability and reliability (...)" (Geiger, Schröder 2014, p. 173). They can be used effectively in institutionalizing of double loop learning processes (Argyris 1976) and ensuring that other routines are still up to date and fit for purpose. Such routines are described as higher level routines (Winter 2003) (Nelson, Winter 1982) or meta routines (Adler et. al. 1999).

On the other hand, the stability and continuity related effects routines have on organizations, may tend to transform at times into negative by-products: bureaucratization, inertia and structural stiffness, which are pointed out by scholars as the main disadvantages of routinization.

Although some critique towards the Routine Theory has been shared (Felin, Foss 2004), it could be said that over the last thirty years it reached a significant level of maturity. Unfortunately the same statement could not be applied to availability of concrete advice for the management practice. The literature neither offers clear solutions on how to effectively deal with routines, nor does it answer many of the practice relevant questions (Kaiser, Kozica 2013, p. 18). Moreover, it seems that within the management practice there is a considerable demand for knowledge and methods on how to effectively and efficiently shape and implement the intended organizational routines.

The present paper addresses this question and aims to describe a possible method of shaping organizational routines. It consists of three major sections. First, two different approaches to routine formation are presented and referred to as evolution and engineering. Subsequently, following case study findings, a different approach is proposed. In the last section, the main aspects of the suggested method are explained and directions for further research outlined.

\section{Evolution and engineering. Different approaches to routine formation}

There are divergent views on routine origin in the rich body of literature. However, one can get a strong impression that the majority of scholars lean toward the hypothesis of routine emergence, i.e. their unplanned evolvement. Keeping in mind that the routine theory develops within the evolutionary stream of management science, such perception of the phenomenon is not surprising. In line with key assumptions of the evolutionary management, being 
close to Hayek's (1980) concept of spontaneous order (ger. spontane Ordnung), researchers support the idea of self-organization. According to the idea of self-organization, the actions carried out by actors in organizations follow patterns which do not have to be designed by anyone. They develop on their own as a result of mutual collaboration and interactions with the environment (Malik, Probst 1981), evolving in consecutive iterations over time, eventually converting into taken-for-granted collaboration patterns (Feldman, Pentland 2003). It is an unplanned, involuntary process, subject only to a small degree to managerial control, in which participants are relatively free to make their choices. Following this perception, routines emerge successively as a result of: trial and error actions (Rerup, Feldman 2011), repetition and recognition (Feldman, Pentland 2003, p. 108), daily direct interaction (Eisenberg, Riley 1988) (Felin et. al. 2012, p. 1363) (Bapuji et. al. 2012), imitation of behavior among employees (Felin, Foss 2005, p. 451), structuration effects of information technology (Orlikowski, Robey 1991), collective learning processes (March, Simon 1958, p. 182) (Cohen, Bacdayan 1996, p. 556), sanctioning of deviations from the agreed patterns by means of social ostracism (Witt 2011).

Both the literature and management practice provide evidence of successful routine formation through unplanned, evolutionary processes. At the same time doubts are raised whether this approach leads to the expected results within acceptable time and cost. Emergence can be longlasting, trial and error may result in high costs and the likelihood that the pattern (evolved) is in line with management expectations is hard to estimate. In addition, trial and error actions carry the risk that in some business domains (customer relations, service and support, process control in process manufacturing, patient care in emergency departments) may be unacceptable. M. Bielski (1997, p. 52) underlines that trial-and-error based management is the more dangerous "(...) the larger the organization and the greater the impact magnitude of the decisions taken". Moreover, A. Kieser and M. Woywode (2006, p. 348) emphasize outright that "(...) complex systems such as organizational structures, cost control systems and manufacturing technologies are nearly impossible to be modified through spontaneous interactions of actors". The evolutionary approach to routine formation doesn't finally explain the frequently encountered, radical reorganizations of enterprises (being part of business process reengineering programs and operating model transformations). A rich body of literature provides evidence that within such programs, strong management involvement and commitment plays a critical role. 
In the evolutionary approach to routine formation, the manager is acting as a moderator, facilitating interaction, encouraging discussion and is far from providing clear orders (Probst 1987). Those expectations towards the role of an executive, are likely to be unacceptable in most businesses. Moreover, some researchers state that such behavior may lead to some pathologies like the contemporarily wide spread phenomenon of "authority without sovereignty" (Sennett 2006).

Treating the evolutionary view on routine origin as one extreme of a continuum, then the hypothesis of their full dependence on formal organizational procedures, could be regarded as the contrary one. Worth mentioning is here, as D'Adderio states, that early scholars of the Routine Theory have given significant attention to artefactual representations, such as rules or standard operating procedures, and their role in production and reproduction of routines which has been rather overlooked in subsequent research (2011, p. 203).

In the most radical view, organizational routines are identified with standard operating procedures (Simon 1976) (March, Simon 1958) (Cyert, March 1963). An alike view, although less extreme, is provided within the conceptualization of organizational routines by D. Geiger and A. Schröder (2014). They claim that organizational routines are "(...) collective performance patterns that are enacted on the basis of rules and their situation-specific interpretation." (Geiger, Schröder 2014, p. 179). The basic elements of this definition, pointing to the origin of routines, are: organizational rules, their interpretation and related performance. Organizational rules are the main foundation of the repetitive interaction of actors. They are seen as "(...) normative behavioral expectations" (Geiger, Schröder 2014, p. 171), which are deliberately designed, implemented and enacted. Key importance is given here to rule interpretation which is the link between formal procedures and their execution. It constitutes a zone of discretion, necessary for efficient adaptation to the changing conditions, which appears to be much smaller in this conceptualization, than in the evolutionary perspective.

Thoughtful shaping of organizational routines is in line with the main approaches to organizational design (and mainly to standardization and formalization) and business process management. It seems to mitigate the disadvantages of the evolutionary approach. Because it is carried out in a controlled way it is believed to be less costly (with regard to learning and implementation) and faster in achieving the expected degree of routine maturity. Furthermore, less discretion is supposed to reduce the risk of not achieving intended outcomes. 
This concept has its own drawbacks. In particular it calls for strong conceptual management skills such as anticipation, synthesis, ability to define rule usage criteria and monitoring mechanisms. Furthermore, its effectiveness largely depends on an appropriate implementation which influences the degree of internalization of rules by the employees. Like in the case of business strategy, it is not solely the strategy definition which ensures success, but its proper implementation and the degree to which it is embedded in daily actions. In the extreme case, the communicated rules may in ignored. From this point of view the implementation of routines could seem to be more effective in the evolutionary approach, where they are shaped through long-term, perpetual iterations. There is, however, always the (mentioned) risk of the outcome not meeting expectations.

Because rules remain unchanged regardless of how they are enacted by actors (as opposed to the ostensive aspect of routines), their routine-shaping effectiveness depends on the degree of consistency between their interpretation and the intentions of the designers. The management practice provides evidence that a simple publication of regulations is usually not sufficient to achieve their expected comprehension. It requires extra effort to verbally communicate the needs, supported by simple examples of usage. An important piece of this work is to obtain employee feedback. Without such supporting activities the probability of failure, seen as routines being enacted differently than intended in the underlying rules, is high.

\section{Shaping application integration routines: a case study}

In order to demonstrate a different approach to the formation of organizational routines, the case of an application integration department has been used. This organizational unit is part of one of the leading companies in the FMCG industry. The analyzed company operates globally and is present in 160 markets. Its origins date back from 1786 but in its current form has been shaped since 1996 when it was first listed on the London Stock Exchange as a FTSE 100 company. Over the past 20 years the company has developed very rapidly, largely through mergers and acquisitions of other companies from the same industry.

The case study covers a period of four years, during which the author was actively involved in the projects described subsequently. It focuses on application integration routines which are essential for effective and efficient (cost, time, quality) delivery of integration services. 
The main research approach was participant observation. Relevant research data was also collected from approximately 3000 internal e-mails, meeting minutes, project steering group records, program and departmental documentation.

The case study makes apparent the various drawbacks and advantages of the evolutionary and engineering approaches and by means of real-life examples creates awareness on how both of them could be combined into a hybrid method, which is supposed to deliver quicker and more solid results.

The main challenges with application integration are closely related to the application architecture of an enterprise. In this case, it is can be characterized by a significant number of standalone systems that support the activities of individual functional areas and/or regions, thus, it follows a best-of-breed approach. This state was on the one hand, the consequence of the way the company developed over the last twenty years (mergers and acquisitions) and on the other, an emergent outcome of inertia and strict focus on business priorities with less attention given to the consistency of the information systems landscape.

In 2011, the company used many different, but rather less advanced, application integration patterns. The main characteristics of the evolved (and not deliberately designed) integration architecture were: the usage of asynchronous integration patterns, such as flat and XML file exchange by means of FTP scripts and based on batch processing, usage of ETL tooling and shared databases, low degree of data standardization and interface reuse, tight coupling of systems through point-to-point interfaces.

Application integration services were historically provided by two centers of excellence (COE) located in The Netherlands and Germany. They offered independent solutions for clearly assigned functional domains. In consequence of the structural separation, different approaches to application integration evolved (at the two locations) in terms of processes, people capabilities and technology. The German COE was delivering almost all of their services via an outsourcing integration service provider and heavily used ETL tooling. Internal employees were playing largely a coordinating role, aligning the service provider work with the business demand and project schedules. In contrast, the Dutch COE was delivering the whole spectrum of integration related activities independently. Internal employees were conducting business requirement analysis, solution design, development, testing, code deployment and hosting. Whenever the capacity was insufficient, the available resource base was scaled up with external contractors being hired on-demand to perform project related activities. Within the Dutch COE the most basic integration patterns were 
followed, with strong focus on point-to-point, file based and batch driven data exchange, not supported by any dedicated middleware. The use of different integration patterns and technologies as well as unalike roles and responsibilities led to the evolvement of different routines for project and service delivery at the mentioned locations.

Despite the large differences in the way of providing solutions, lack of synergy and inconsistent integration architecture, there was no pressure to change the status quo because the separated functional domains were supported timely and at acceptable cost.

The situation was aggravated around 2010 - 2012, when the European Commission introduced legal obligations (within the industry the company is operating) to track and trace the company's finished goods (on shipping case level) throughout the supply chain, from the moment of their manufacturing at the plant until the sale to the first wholesaler. The consequence of these new regulations were: an enormous increase in data exchange (both in terms of volume and frequency) between the different information systems and the need for extensive adaptation work in the field of application integration. To address the challenge a decision was taken to implement an Enterprise Service Bus (ESB), a highly performant message oriented middleware, enabling a more looselycoupled information system landscape through the use of publish-subscribe integration patterns and canonical data models, establishing a single point of control for interfaces, ensuring their better transparency and facilitating their reuse. The ESB selection and deployment decision was followed by a half year pilot project, which was successfully delivered in late 2013 by representatives of both COEs.

After the completion of the pilot project, the roll-out activities were started aiming at the deployment of the (newly created) integration solutions within all the company's manufacturing plants (impacted by the new regulations) and within its supply chain.

In the course of the pilot project the need for new, more professional and aligned, organizational routines became apparent. They were related in particular to demand and resource management, project delivery and change management, software quality assurance and testing, (software) vendor and service provider management, design and maintenance of integration standards and guidelines, operational and technical application management, application integration strategy development and road mapping, knowledge retention and the institutionalization of learning processes as well as continuous improvement practices. 
Effective and efficient realization of these routines is essential for professional integration service delivery in almost any enterprise in which the communication between different applications plays a key role in ensuring a smooth execution of its business processes. Also in the case of the analyzed company such need was recognized and first steps to design and implement the relevant routines were made by the end of 2013.

In order to address this challenge the so-called governance work stream was set up (within the roll-out project) with the goal to establish appropriate standards and guidelines as well as to design new patterns for the routines mentioned. After six months of work a team led by external experts, consisting of representatives from both COEs, worked out (in isolation from the delivery team) the new "to-be" routines.

In parallel, the delivery team, responsible for the migration activities, developed in an uncontrolled manner its own routines. Here, a significant impact on the shape of the evolved ways of working had the suggestions from the engaged external consultants. In this way, e.g. within project delivery and change management activities, elements of the agile methodology were adopted. Requirements were translated into user stories, placed on the scrum board and planned within bi-weekly sprints. Every morning a 15 minute standup was carried out in which past work, planned tasks and impediments were discussed. At the end of each sprint a review was conducted. There was a good atmosphere within the team, staff became familiar with the scrum approach and after about 6 months this way of working became routine. From a delivery team member perspective, commonly accepted and well-established routines had evolved, within a reasonable timeframe, with almost no need for management involvement.

When the management team, involved in the governance work stream presented the outcomes of their work, resistance was evident. The routines designed by the leadership team were considered too advanced for the current integration maturity level of the enterprise. Furthermore, arguments were raised "(...) to not change smoothly working routines when there is no need to do so and projects are delivered on time and in budget". Eventually, the management team followed the delivery team's suggestion and didn't force the enactment of the routines designed in the governance work stream.

After thefirst successful migrations the benefits of middleware based integration solutions were spotted by different functional departments. In parallel, new developments within the application architecture led to a significant increase in the demand for integration solutions. Considerable programs were launched 
aiming (among others) at implementing: a best-of-breed CRM cloud solution, a product lifecycle management system, new asset management application and a novel HR system. On top of it, new projects were started with the objective to migrate the existing interfaces onto the new integration platform.

This demand peak clearly led to an increase in the workload of the integration delivery team. Nevertheless, resource capacity requirements were quite easily covered with external contractors and by delivering more services through the outsourcing partner of the German COE. It is worthwhile to mention that in parallel, a structural transition was accomplished and both of the COEs have been merged into a single unit with the objective to cover the company wide demand for application integration.

However, after a while, symptoms of an underlying problem became apparent. Quite frequently, tasks weren't delivered on time and took more effort than originally expected. Communication between the delivery (scrum) team and the parent projects became cumbersome and increasingly difficult. At the end of 2014, when the budget of one of the projects was significantly overspent, the leadership team realized that the enacted project delivery routine was a poor fit with the organizational context. In particular, the coordination of the development and system testing activities, conducted in bi-weekly sprints, and the parent projects was taking a lot of time and was often ineffective. Similar issues could be attributed as well to the work organization of the scrum team itself which was delivering solutions to a magnitude of projects, each following its own schedule and priorities. Developers often had to work simultaneously on multiple solutions originating from different functional domains. Furthermore, frequent changes in the parent project schedules were not timely communicated to the scrum master. Consequently, last minute actions were often taken to meet the new due dates and the scrum board became a mess. It lead to widespread frustration, conflicts and escalations as well as to increasingly frequent questioning of the competency and level of professionalism of the application integration department by other functional areas of the company. Despite the assignment given, the team failed to deliver the integration standards and guidelines. Additionally, the knowledge retention and sharing routines weren't institutionalized at all. Learning was highly individual, continuous improvement processes were non-existing and the same mistakes were often repeated.

Recognizing the severity of the situation the management became more involved in the shaping of routines. The main cause of the issues described was quite quickly identified. The scrum approach was simply not fitting an environment where most of the projects were delivered following a waterfall 
methodology. Corrective measures were applied and the work of the integration team was reorganized. Individual developers and integration consultants were assigned directly to the parent project teams. The demand and resource management processes remained with the integration department. The overall delivery routine was redesigned, starting from requirements' analysis and ending up with the code deployment into the production environment and handover to the support desk. The middleware operations department provided acceptance criteria for taking over the solutions from the project teams. Quality gates were established (design and code review, acceptance testing) as well as document templates, intended for use at different stages of the delivery process. Development standards and guidelines were created in order to ensure the consistency of solutions and fostering the reuse of different components. Once designed, new standards and espoused routines were communicated to the employees.

The measures taken delivered quick results. The direct involvement of consultants and developers in the project teams increased their productivity and improved the transparency of project schedules and critical milestones. The need for continuous alignment of the development activities with higher level project demand was significantly reduced. Although the consultants and programmers were working temporarily in separate (project) teams, they were asked to follow the development guidelines. In this way both responsiveness (to project demand) and consistency of solutions were expected to be ensured.

The most significant routines (project delivery, quality assurance, creation and maintenance of the standards and guidelines) of the application integration department were reengineered. The leadership team had driven the definition of most of them together with the most senior employees and external consultants. The redesign was accomplished nearly within 6 months. During that time several projects were slightly delayed. This time was necessary though (for the people involved) to step out of the operational activities and work out the new standards and patterns.

Although the situation seemed to be "back on track", new issues were observed. The developed guidelines were at times interpreted in a way which wasn't intended by its designers. The lead developer, responsible for the solution design and code reviews, interpreted them almost literally, asking frequently the designers and developers to rework their solutions in order to comply with the guidelines. The guidelines were however intended by their designers to provide direction, to standardize the solutions for given categories of requirements and meant to be a "living" document which would be regularly 
updated with new insight when encountering previously unforeseen problems. In summary, the interpretation of the guidelines by the actors involved was simply different from the intentions of their originators. It was mainly caused by insufficient explanation of their purpose and by not providing the team with examples of their possible application. In case of conflicts, related to the different interpretation of the standards, the affected employees contacted the leadership team to get a final decision, avoided furthers action in order to prevent mistakes or decided how to continue on their own. The final choice depended largely on the personality of the employee and his/her experience.

The interpretation of the rules were not the only problems encountered. It turned out that some routines which required creativity (e.g. designing solutions) have become over-formalized, and others, where strict following of the espoused pattern was essential, were not sufficiently controlled on compliance.

Despite the general recognition of the progress in the professionalization of integration services and related routines, which took place in 2015, there was still room for improvement.

In the first step the routines were classified as creative or operational. In the case of the creative ones (e.g. solution design, standards \& guidelines development, incident management and related investigations, integration strategy definition and related road mapping), no single best practice for execution could be determined upfront. On the other hand, the operational routines were supposed to be carried out in predominantly stable and repeatable situations. In their case, value was added when they were being executed closest to the designed pattern (e.g. software quality control, demand and resource management, project delivery).

The mindful shaping of the creative routines was mainly driven by a precise clarification of the routine's purpose and related expectations. To ensure that their enactment will be closest to management intentions, attention was given to staff development (skills) and promotion of particular values (organizational culture). Routine participants were also provided with various supporting tools, such as checklists, specifying the factors that were key to the effectiveness of particular routines (e.g. when designing integration solutions, in addition to the functional requirements, following elements are to be considered as well: security and non-repudiation, expected availability and performance, error handling, resilience and maintainability).

With regard to the operational routines, detailed process maps were developed specifying in detail the workflow of activities, responsibilities, checkpoints and handover points. Additionally, the designed workflow was implemented 
in an information system which facilitated the cost, time and progress control. The usage of the system led to the unification of communication patterns (e.g. developers quickly adopted the terminology of the application) which increased communication quality.

Subsequently, a decision was made to involve the most experienced employees in the process of rule definition which were meant as the foundation for the routines. To ensure the efficiency of this method, the management team was initiating the process and designing the first drafts of the procedures which were then consulted with the employees engaged in this process. Staff was encouraged to challenge the designs in order to perform a kind of theoretical stress test. Based on the feedback received the final versions of the procedures were developed.

In this phase the purpose and the main expectations of the newly standardized processes were clarified, to ensure that its further interpretation will be in line with management intentions. The employees involved were then asked to explain the newly designed routine to their colleagues and to justify it. In this sense they acted as change agents.

Later on, as soon as it was possible the future routine participants were asked to carry out their activities according to the new pattern. Compared to the previous phase, more management attention and involvement was ensured. The goal was to develop as fast as possible staff capabilities to execute the routines in line with the new patterns (known in the literature as knowing - Orlikowski 2002) Gheradi 2000, as opposed to knowledge development).

Being aware of the nature of typical learning processes (learning curve) the leadership team sought to accelerate them. Theoretical, class room like education was almost skipped for the sake of learning by doing. Low risk projects were identified and assigned to the employees who were asked to use the new patterns straight away. In these controlled conditions, the routine participants were encouraged to experiment with the new routines in order to gain first experiences. The management team was aware that such proceedings will inevitably lead to some employee made mistakes. It was accepted though (as a kind of calculated risk) as it was assumed that trial and error learning within controlled conditions will faster develop employees' knowing than classic education. In this way, consciously, an environment has been shaped where the sensemaking activities (Weick 1995) could be accelerated.

In order to further increase the efficiency of the learning processes, the routine participants were provided with a number of support tools. In the case of the operational routines, process maps and procedure descriptions were handed 
over. Short training was given on how to enact the new routine by means of an information system where the workflow was configured in line with the new pattern. For the creative routines, checklists were provided together with access to available knowledge bases.

In the early stages of the controlled learning phase, the management team was actively involved in the execution of routines, providing examples of the expected routine realization. This was particularly important in the case of creative routines, where from time to time clarity had to be given about how to decide in unclear or ambiguous situations (e.g. when designing solutions and/ or addressing new and previously not encountered integration scenarios, it was stressed that the maintainability and the related support cost were far more important than the degree of technological advancement). Management were also actively involved whenever the espoused routine pattern was bypassed through various workarounds. When gaps were identified a note was taken and discussed in a weekly meeting in order to find the most suitable way to address them. On the other hand, if the enactment of the routine differed substantially from the design and could not be plausibly justified, actions were taken to prevent this from happening again. It was subsequently observed that these situations could be mostly attributed to a kind of cultural misfit, between the routine being adopted and the main principles underlying the previous way of working. Having identified the root cause, the leadership started to proactively promote new values, consistent with the new routines, and suppress the misaligned ones (such management attitude seemed to facilitate routine embedment which was also exemplified in some other case studies in the literature on routines; see the Northsite's example in Bertels et. al. 2016).

Additionally, weekly team meetings were held where employees were encouraged to share information about the errors committed and to exchange experiences on how the mistakes became eventually corrected (single loop learning). Furthermore, common reflection has been stimulated on whether the newly implemented routines are fit for purpose and what aspects could be still fine-tuned (double loop learning). These discussions were aiming at establishing a continuous improvement culture within the application integration team and at creating a working atmosphere where the status quo could be constructively challenged at all times.

An important role in "freezing" of the newly implemented routines was the regular communication of project success. It raised routine participants' confidence in the appropriateness of the enacted ways of working.

Once the initial phase of controlled learning was completed, the newly formed 
routines were applied to higher rank projects and initiatives. At this stage, the management team reduced their involvement in direct activities but assured their availability and conducted frequently coaching conversations. The aim here was to identify actions that still posed difficulties and to help the employees to overcome the related challenges on their own. In parallel to the progressing embedment of routines, the leadership team was gradually stepping back whilst increasing the autonomy of routine participants. Weekly team meetings were still held as well as the daily stand-ups. It helped to further strengthen the atmosphere of open communication and feedback sharing which eventually led to the institutionalization of double loop learning within the application integration team.

After four years of searching for a suitable method of shaping application integration routines, an approach has been identified which allowed for effective (compliance with designers' intentions) and efficient (cost and time) routine implementation. The concept received recognition of the senior management and attempts were made to use it in other functional areas.

The process of developing several organizational routines within the application integration department offers a good insight into the effectiveness and efficiency of the different approaches to routine formation. This can be attributed to the variable character during the period described In 2013 and 2014 it resembled rather the (described above) evolutionary drift, whereas in 2015 it was driven by well-defined standard operating procedures. Latterly in 2016, the expected level of routine efficiency was reached by means of a hybrid approach which focused on controlled learning and prompt usage of newly designed routines.

Changes to the routine formation approach were related to the different undertakings aimed at the mitigation of drawbacks from earlier initiatives. The phase of spontaneous evolvement (2013-2014) led to the emergence of routines which were incompatible with others. In turn (in 2015), the phase where routines were supposed to be driven by standard operating procedures led to issues with the unexpected diversity of rule interpretation, over-formalization and insufficient rule compliance control. Eventually (mid-2015 to mid-2016), a hybrid approach was chosen in which the advantages of the previous initiatives were leveraged and the disadvantages mitigated.

\section{Conclusions}

The approach (chosen ultimately) was labeled as "controlled learning" mainly because of the priority given to the experimentation with new patterns of action 
under controlled conditions (low-rank and low-risk projects) and encouraging learning by doing. Within this concept selected elements of various leadership practices are applied (participation, transformational leadership, coaching) and supportive tooling (artifacts) is provided to the routine participants in order to facilitate the routine embedment and the related learning (process maps, instructions, workflows, checklists, knowledge base). It differentiates between creative (also called as flexible) and operational routines (a classification recognized recently as well by other scholars; see e.g. Danner-Schröder, Geiger 2016).

The described method should be seen, as it is frequently the case in the organization theory and management practice, as an attempt to find the right balance in applying the elements from two distinct approaches to routine implementation, referred in this paper as "evolution" and "engineering". Its most significant elements are presented in figure 1.

The approach has a hybrid character and highlights the central role of the implementation phase which determines its effectiveness and efficiency. As mentioned, it addresses the disadvantages of the "evolutionary" and "engineering" methods of routine formation and attempts to leverage their advantages. It ensures efficiency in the design phase and aims at delivering relatively fast acceptable (by employees) routine proposals. The initial design is provided by the management (engineering aspect) in order to secure its alignment with the organizational goals and shorten the time required to come up with initial proposals (e.g. in the evolutionary approach numerous discussions amongst staff would be potentially required to come up with a first draft which would likely take a lot of time). Employee participation (evolutionary aspect) raises in turn the likelihood of acceptance, as it stresses the importance of the point of view of the future routine participants. As a result, at the very beginning of the routine shaping process appropriate measures are applied to enable afterwards a smooth implementation (which is often overlooked is the engineering approach).

The subsequent communication phase is intended to ensure the clarification of the routine purpose and to explain how it should be correctly carried out. Properly conducted, it should bring about a common understanding of the interaction pattern and shorten the implementation and learning phase. In the engineering approach the need for intensive communication is often underestimated, and in the evolutionary one, left uncontrolled. It leads respectively to an excessive diversity of rule interpretation or to an emergence of patterns which are substantially different from management expectations. 


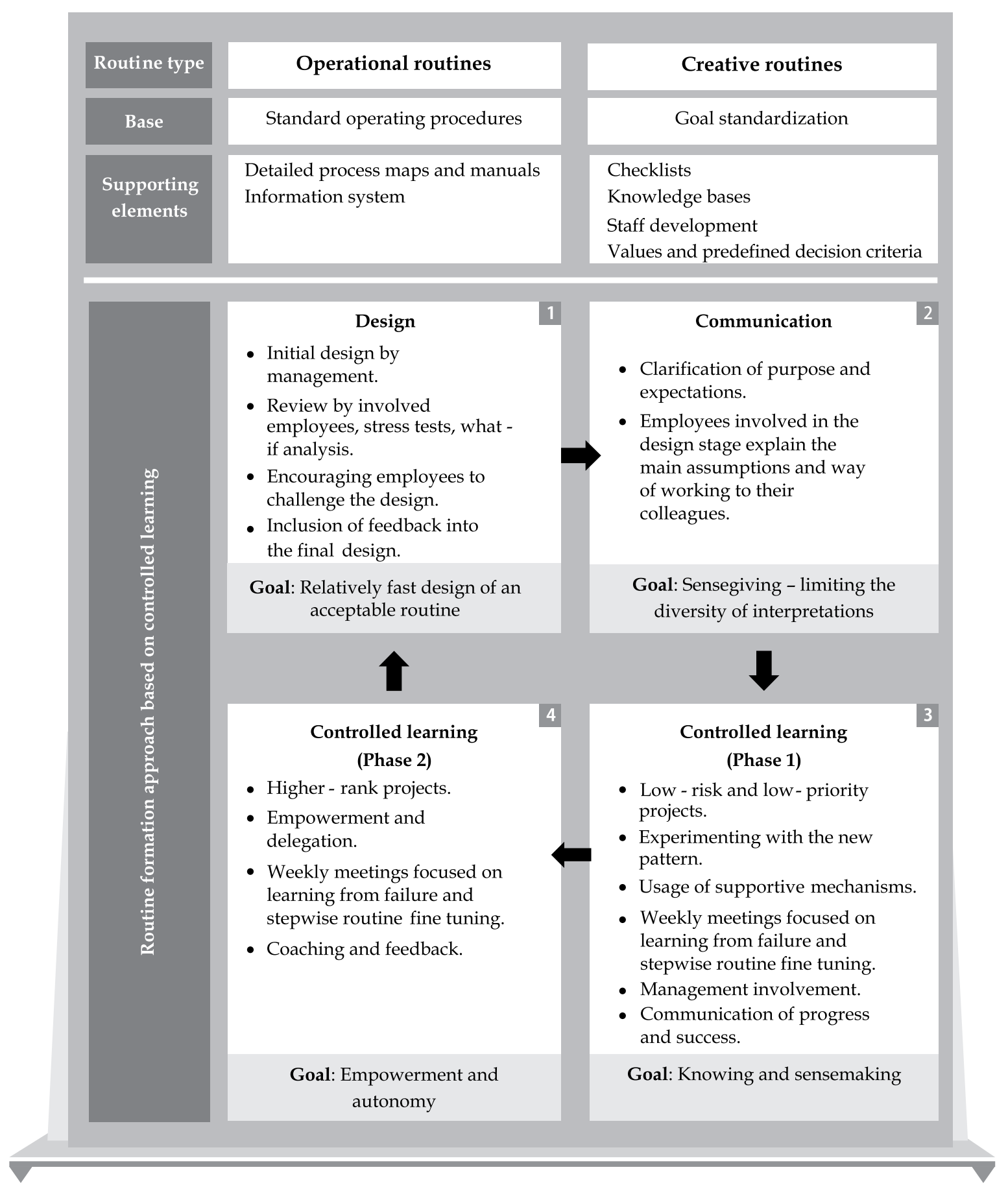

Figure 1. Routine formation approach based on the controlled learning process

Source: own study 
The controlled learning phases are focused on the fast development of knowing (phase 1) and on staff empowerment (phase 2). The experimentation under controlled conditions leads to a faster embedment of routines (compared to the evolutionary approach). The close cooperation with the leadership team increases the likelihood of routine alignment with managerial intentions. Intensive management involvement in phase 1 facilitates as well prompt course corrections, in the case of deviations from the designed pattern, and stresses the importance of the newly implemented routine.

The usage of the "controlled learning" method seems to lead to a faster and less expensive embedment of the espoused routines in organizations. It is supposed to increase the likelihood of their internalization (by routine participants) and to lead to a better compliance with the original design.

It should be noted, however, that the developed method was created in a specific organizational context. Thus, the degree of its universality should therefore be subject to empirical verification on a larger sample of firms (to which the author encourages researchers). It also seems that the proposed approach indirectly draws attention to one of the important aspects of routine development - the enabling effects of different kinds of support mechanisms (i.e. artifacts). In this way, it points at the existence of a number of factors that can streamline or inhibit the formation process of organizational routines. The author is convinced that the identification of such set of factors and the determination of their routine shaping strength, within different types of organizational contexts, would significantly broaden the understanding of the routine origin and enrich the available managerial repertoire.

\section{Summary}

\section{In search for effective methods of routine formation}

Organizational routines are a frequently researched phenomenon in contemporary management science. Although the available theoretical foundations of Routine Theory seem to have reached a significant degree of maturity over the last thirty years, the same could not be said about the availability of material advice for the management practice. This paper addresses this gap and proposes a framework for an effective routine shaping process. It builds on a brief analysis of available literature on routine formation, supported by case study findings. The approach proposed stresses the importance of the controlled learning process and underlines the importance of deliberate 
implementation, in contrast to the evolutionary and engineering views on routine emergence.

Keywords: organizational routines; application integration; routine implementation; controlled learning.

\section{Streszczenie}

\section{W poszukiwaniu skutecznych metod kształtowania rutyn organizacyjnych.}

Rutyny organizacyjne są obecnie często analizowanym zjawiskiem we współczesnej nauce o zarządzaniu. Jakkolwiek wydaje się, że Teoria Rutyn osiągnęła na przestrzeni ostatnich trzydziestu lat przyzwoity poziom dojrzałości, to nie można tego samego powiedzieć o dostępności konkretnych zaleceń dla praktyki zarządzania. W niniejszym artykule podjęto próbę wypełnienia tej luki poznawczej i zaproponowano jedno $\mathrm{z}$ możliwych podejść do skutecznego kształtowania rutyn organizacyjnych. Opracowano je na podstawie przeglądu literatury przedmiotu oraz wniosków płynących $\mathrm{z}$ analizy studium przypadku. Przedstawiona metoda podkreśla wagę kontrolowanego uczenia się i świadomej implementacji rutyn, kontrastując jednocześnie zarówno z ewolucyjnym, jak i inżynierskim podejściem do ich kształtowania.

\section{Słowa}

kluczowe: rutyny organizacyjne; integracja aplikacji; implementacja rutyn; kontrolowane uczenie się.

\section{References}

1. Adler P.S., Goldoftas B., Levine D.I. (1999), Flexibility versus Efficiency? A Case Study of Model Changeovers in the Toyota Production System, Organization Science, Vol. 10, No. 1, January-February 1999, pp. 43-68.

2. Argyris C. (1976), Single-Loop and Double-Loop Models in Research on Decision Making, Administrative Science Quarterly 21, 363-375.

3. Bapuji H., Hora M., Saeed A. M. (2012). Intentions, intermediaries, and interaction: Examin-ing the emergence of routines. Journal of Management Studies, 49(8), 1586-1607.

4. Becker M.C. (2004), Organizational routines: a review of the literature, Industrial and Corporate Change, Vol. 13, No. 4, pp. 643-677. 
5. Becker M. C. (2008), The past, present and future of organizational routines: introduction to the "Handbook of Organizational Routines". The handbook of organizational routines, Edward Elgar, Cheltencham (UK), Northampton (US), 3-14.

6. Bertels, S., Howard-Grenville, J. and Pek, S. (2016) Cultural molding, shielding, and shoring at Oilco: The role of culture in the integration of routine', Organization Science, 27 (3), pp. 573-593.

7. Bielski M. (1997), Organizacje. Istota, struktury, procesy, Wydawnictwo Uniwersytetu Łódzkiego, Łódź.

8. Cohen M.D., Bacdayan P. (1994), Organizational Routines Are Stored As Procedural Memory: Evidence from a Laboratory Study, Organization Science, Vol. 5, No. 4., pp. 554-568.

9. Cyert R. M., March J. G. (1963), A Behavioral Theory of the Firm. Englewood Cliffs, NJ, 2.

10. D'Adderio, L. (2011), Artifacts at the centre of routines. Performing the material turn in routines theory, Journal of Institutional Economics, 7, pp. 187-230.

11. Danner-Schröder A., Geiger D. (2016). Unravelling the motor of patterning work: Toward an understanding of the microlevel dynamics of standardization and flexibility. Organization Science, 27 (3), 633-658.

12. Eisenberg E. M., Riley P. (1988), Organizational Symbols and Sense-Making, [in:] Goldhaber, Gerald M./Barnett, Géorge A. [in:] Handbook of Organizational Communication, Norwood, N.J., pp. 131-150.

13. Feldman M.S., Pentland B.T. (2003), Reconceptualizing Organizational Routines as a Source of Flexibility and Change, Administrative Science Quarterly, 48, pp. 94-118.

14. Felin T., Foss N. J. (2004), Organizational Routines A Sceptical Look (No. 04-13), DRUID, Copenhagen Business School, Department of Industrial Economics and Strategy/Aalborg University, Department of Business Studies.

15. Felin T, Foss N.J., Heimeriks K.H., Madsen T.L. (2012) Microfoundations of routines and capabilities: Individuals, processes, and structure. J. Management Stud. 49 (8), pp. 1351-1374.

16. Geiger D., Schröder A. (2014). Ever-changing routines? Toward a revised understanding of organizational routines between rule-following and rulebreaking. Schmalenbach Business Review: ZFBF, 66(2), pp. 170-190.

17. Gherardi S. (2000). Practice-based theorizing on learning and knowing in organizations. ORGANIZATION-LONDON-, 7(2), pp. 211-224.

18. Hayek F.A. (1980) Recht, Gesetzgebung und Freicheit, Bd. I: Regeln und Orgnung. München

19. Kaiser S., Kozica A., (2013), Organisationale Routinen. Ein Blick auf den Stand der Forschung, Organisations Entwicklung, No. 1, pp. 15-18

20. Kieser A., Woywode M. (2006) Evolutionstheoretische Ansästze, [in:] Kieser 
A., Ebers M. (eds.), Organisatiostheorien, 6 Auflage, Kohlhammer, Stuttgart.

21. Kieser, A., Walgenbach, P. (2003), Organisation, 4., überarbeitete und erweiterte Auflage. Stuttgart: Schäffer-Poeschel.

22. Malik F., Probst G., (1981), Evolutionäres Management, Die Unternehmung 35: pp. 121-140.

23. March J. G., Olsen J. P. (1976), Ambiguity and choice in organizations. Universitetsvorlaget, Oslo.

24. March J. G., Simon H. A. (1958), Organizations, New York.

25. Nelson R. R., Winter S. G. (1982), An Evolutionary Theory of Economic Change. Cambridge.

26. Orlikowski W. J. (2002). Knowing in practice: Enacting a collective capability in distributed organizing. Organization science, 13 (3), pp. 249-273.

27. Orlikowski W. J., Robey D. (1991), Information technology and the structuring of organizations. Information systems research, 2 (2), pp. 143-169.

28. Probst G., (1987), Selbst-Organisation. Ordnungsprozesse in sozialen Systemen aus ganzheitlicher Sicht. Berlin.

29. Rerup C., Feldman M. S. (2011). Routines as a source of change in organizational schemata: The role of trial-and-error learning. Academy of Management Journal, 54 (3), pp. 577-610.

30. Sennett R. (2006), Korozja charakteru. Osobiste konsekwencje pracy w nowym kapitaliźmie. Warszawa.

31. Simon H. A. (1976), Administrative behavior; a study of decision-making processes in administrative organization-3. New York

32. Walsh, J. P., Ungson, G. R. (1991), Organizational memory. Academy of management review, 16 (1), pp. 57-91.

33. Weick, K. (1995). Sensemaking in Organisations. London: Sage

34. Winter S.G. (2003). Understanding dynamic capabilities. Strategic management journal, 24 (10), pp. 991-995.

35. Witt U. (2011), Emergence and functionality of organizational routines: an individualistic approach, Journal of Institutional Economics 7.02, pp. 157174 . 